\title{
"HAVING FELLOWSHIP WITH GOD" ACCORDING TO 1 JOHN: DEALING WITH THE INTERMEDIATION AND ENVIRONMENT THROUGH WHICH AND IN WHICH IT IS CONSTITUTED
}

\author{
D.G. van der Merwe ${ }^{1}$
}

\begin{abstract}

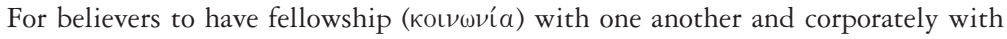
God, is one of the main objectives stated for the proclamation of the gospel by the author of 1 John. This article investigates the intermediation and environment through which and in which fellowship is constituted between God and his children. From the prooemium (1:1-4) of the epistle, which is used as the basic text in this research, Jesus Christ, the Son of God, has been designated (as i $\lambda \alpha \sigma \mu$ ós in 2:2; 4:10 and as

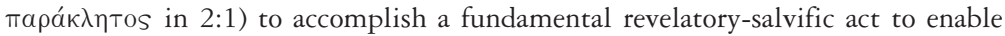
believers to have fellowship with God and one another. This concept of fellowship, used in a familial sense, is described from the symbolic narrative of family life where

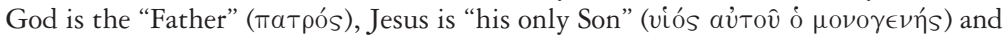
believers are the "children of God" ( the individual child of God $(2: 20,27 ; 5: 20)$, but qualifies this emphasis with the

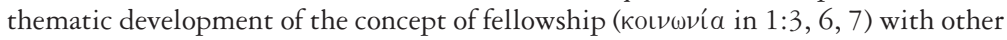
believers in the familia dei. The joy of believers in this familia dei, as an outcome of this fellowship, only becomes "complete" ( $\pi \epsilon \pi \lambda \eta \rho \omega \mu \epsilon \in \eta \eta)$ where fellowship is constituted both among God's children and corporately with God.
\end{abstract}

\section{INTRODUCTION}

A large volume of academic and popular publications ${ }^{2}$ on the subject "spirituality" has been published during the last decade within the context of various religions, ${ }^{3}$ dealing with various aspects of spirituality.

1 Prof. D.G. van der Merwe, University of South Africa, Pretoria. 0003.

2 In two of the largest South African universities' libraries, namely UNISA and the University of Pretoria, a search was done on books containing the keyword "spirituality." In UNISA's library, 1427 books were found, in the library of the Univerity of Pretoria 218 books and in the library of Rhodes University 263 books.

3 The vast majority relates to the Christian religion. 
Even an Internet search on this subject revealed 7,5 million sites in which the noun "spirituality" occurred. This provides some insight into the vast interest on this topic world wide. Unfortunately, in the above search nothing could be found on "spirituality in 1 John." article endeavours to scrutinise what 1 John in particular reveals about the two specific aspects on the concept of Christian spirituality as indicated in the title.

According to the Open Bible (1985:1272), the major theme of 1 John is "fellowship with God." ${ }^{5}$ The Elder ${ }^{6}$ wants his adherents to have assurance of the indwelling God through their abiding relationship with Him (cf. $2: 28 ; 5: 13$ ). According to this statement, the denotation of "fellowship with God" falls within the semantic field of "Christian spirituality" (with its numerous nuances of meaning). In this article the subject matter of "fellowship with God" will be investigated from the perspective of the intermediation and environment through which and in which "fellowship with God" is constituted and has to be construed according to 1 John.

4 This search was done on the "Google" search engine (Google.com). This number also includes spirituality in other religions. A search under "Spirituality in 1 John" did not show any results. A search under "Johannine Spirituality" indicated 115 sites, but only on the Gospel and Revelation. Thus, no publications could be found on "Spirituality in 1 John." Therefore, this article can probably be seen as the first contribution and publication on "Spirituality in 1 John."

5 Cf. also Culpepper (1998:255); Edwards (1996:70f.); Grayston (1984:45). Within scholarship two distinct and disparate views have developed concerning the message of 1 John. They have arisen as a consequence of two variant perceptions of the purpose of the epistle. The one comprises "salvation" ( $\dot{\eta} \zeta \omega \eta \dot{\eta} \dot{\eta}$ aívıเos)

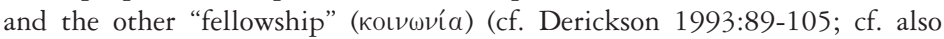
Kenney 2000a). In fact they complement one another. Both these themes are mentioned in the prooemium of 1 John, where the author provides, as may be expected, a synopsis of his principal motifs.

6 In this study it has been accepted, in agreement with the point of view of most scholars, that the three Johannine epistles were written by the same person, re-

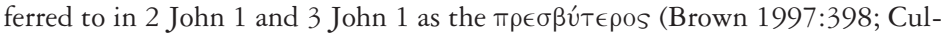
pepper 1998:251; Kenney 2000b:12; Painter 2002:18). Therefore, in this document, the author will be referred to as "the Elder". 
To accomplish this, the prooemium (opening statement, 1:1-4) has been chosen as point of departure. ${ }^{7}$ Methodologically, a discourse analysis of the prooemium will be conducted to determine the structure, rhetoric and focus area of the text, as well as the theoretical account of argumentation in this article. Exegesis, embedded within the framework of the socio-religious circumstances in which 1 John was written, will then be conducted. A brief analysis of the socio-religious situation in the Johannine community at that point in time follows.

\section{THE SITUATION IN THE JOHANNINE COMMUNITY}

A schism (2:18-23) occurred in the Johannine community, owing to opposing interpretations of the Gospel message. A look into the historical circumstances that caused the schism reveal that First and Second John depict a community torn apart by doctrinal and ethical differences. 1 John 2:18-19 indicates that there had been a time when those who caused the schism ${ }^{8}$ were not differentiated from the adherents of the Elder.

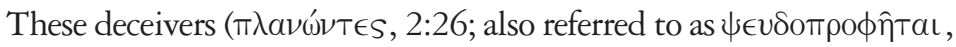

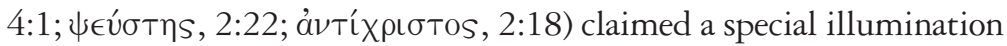
by the Spirit $(2: 20,27)$ that imparted to them the true knowledge of God. This caused them to regard themselves to be the children of God. They claimed that their Christological views and their own spiritual status were superior (Hurtado 2003:416). It seems as if they believed that they had been given a new and superior insight. They also may have claimed that they possessed (or had been given) fellowship

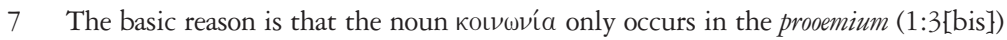
in conjunction with $1: 6,7$, although this concept is also inferred throughout 1 John.

8 Many attempts have been made to identify the opponents of 1 John. Unfortunately none of these identifications are convincing. Therefore, we can agree with Edwards (2000:161; see also Du Plessis 1978:101) that we cannot negate the existence of "opponents" or "deceivers," but that the precise historical situation cannot be reliably reconstructed. However, from the text it is possible to make some deductions about how their beliefs influenced the polemic-pastoral message of the elder. 
with God that was superior to that enjoyed by other Johannine Christians, and that their higher spiritual status justified severing ties. It seems as if they were sufficiently persuaded of the superiority of their inspiration that they removed themselves from the circle of Johannine Christianity (Hurtado 2003:424). This explains the strong emphasis by the Elder on the knowledge of God, the way in which he and his adherents became children of God (to receive salvation; 5:1-5) and their conduct as children of God. He contrasts the heretics' claim to knowledge with the knowledge that can come only from the Christian tradition (2:24).

Through this spiritual illumination, these heretics claimed to have attained a state beyond ordinary Christian morality in which they had no more sin and attained moral perfection (1:8-10). This group taught that all believers had been delivered from sin and had already crossed from death into life (1 John 1:8, 10; 3:14), and have fellowship with God (1:6). This strong emphasis on realised eschatology led to a disregard for the need to continue to resist sin. Their chief ethical error appears to be a spiritual pride that led them to despise ordinary Christians who did not claim to have attained the same level of spiritual illumination. The elder warns his readers against claiming to be without $\sin$ (1 John $1: 8-22)$. He admonishes those who claim to know God, but disobey His commandments ${ }^{9}(1: 6-7 ; 2: 4-6 ; 5: 2-3)$, or who claim to love God, but do not love their brothers (and sisters) $(2: 7-11 ; 3: 10-18,23 ; 4: 7-$ $11,20-21)$. He also cautions against loving the world and warns against its power and temptations $(2: 15-17 ; 4: 4-6 ; 5: 19)$. These admonitions focused on the way of life of those who claimed to be children of God.

This perception influenced their perception of Jesus and advocated a "higher" Christology that emphasised the divinity of Christ, while minimising the humanity of Jesus (1 John 2:19; 4:2) (Kenney 2000b: 101; also Brown 1982:52; Lieu 1986:207). They denied the Incarnation $(2: 22 ; 4: 1)$. Because they believed that matter was ipso facto evil, they

9 Von Wahlde (1990:69) points out that the Elder attributes the commandments to God (their ultimate source), rather than to Jesus, because the opponents questioned the role of Jesus. According to him, the Johannine community focused on two requirements: that the adherents of the Elder "keep the words of Jesus" and that they "love one another." 
believed that God could not possibly have come into direct contact with the natural world through Christ. Therefore they denied the incarnation in general terms. They went even further by denying the reality of Jesus' suffering. They accepted his baptism, but refused to accept the passion as part of the messianic work of salvation (5:6). A host of statements in the epistles can be pieced together in an effort to characterise the teaching of the false prophets. There are series of statements that indicate a serious disagreement about the person of Jesus Christ (1 John 2:22; 4:2, 3, 15; 5:1, 5, 6, 10, 13; 2 John 7). Together these statements yield a list of what the Elder urges his readers to believe and confess: Jesus is "the Messiah"; he has "come in the flesh"; he is "the Son of God"; he came by "water and blood". In other words, they have to "believe in" Jesus $(3: 23 ; 5: 1,5,10,13)$ and "confess" $(2: 22,23)$ him.

It therefore seems clear that the controversy in the Johannine Community was based on differences in the interpretation of a shared tradition (Kenney 2000b:102; Culpepper 1998:253). For this reason the

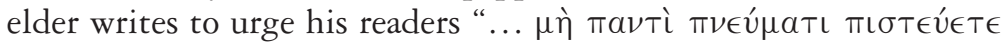

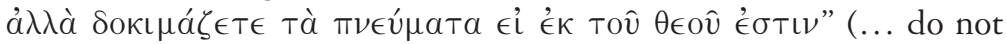
believe every spirit, but test the spirits to see whether they are from God - 4:1). This implies that they are to measure the charismatic utterances of all so-called prophets by the norm of the sound Christian tradition, at the centre of which is the real Incarnation of Christ (4:2-3). In response to this crisis, the Elder wrote 1 John to warn the community of the dangers of this false teaching, to correct this false teaching and to encourage those who remained to continue in their faithfulness. ${ }^{10}$

From the point of view of their "experience of fellowship with God" we can conclude that the Elder wants to warn his adherents that this false teaching, the denial of Jesus' Incarnation, would lead to an existence without experiencing fellowship with God and God's Son. The correction of this false teaching would be to explain how to become children of God and what it comprises to have fellowship with God. The encouragement of God's children would be to point out to them that they may be assured that through their faith in the Son of God (which implies obedience to his commandments), they have eternal life and

10 According to Painter (2002:115), the Elder had a double purpose for writing 1 John: to oppose the heretics and to encourage the believers. 
can already experience fellowship with God. This means that, through Christ, they have already partaken in the life of God.

\section{DISCOURSE ANALYSIS OF 1 JOHN 1:1-4}

A discourse analysis of 1 John 1:1-4 to determine the structure, rhetoric and focus area of the text and the theoretical account of argumentation in this article, follows. A more detailed exegesis with consideration of the possible hypothetical-structured circumstances of the readers that constitutes the setting in which our text is embedded and has to be understood, is subsequently given.

\subsection{A discourse analysis}

Linguistic relations

Semantic relations

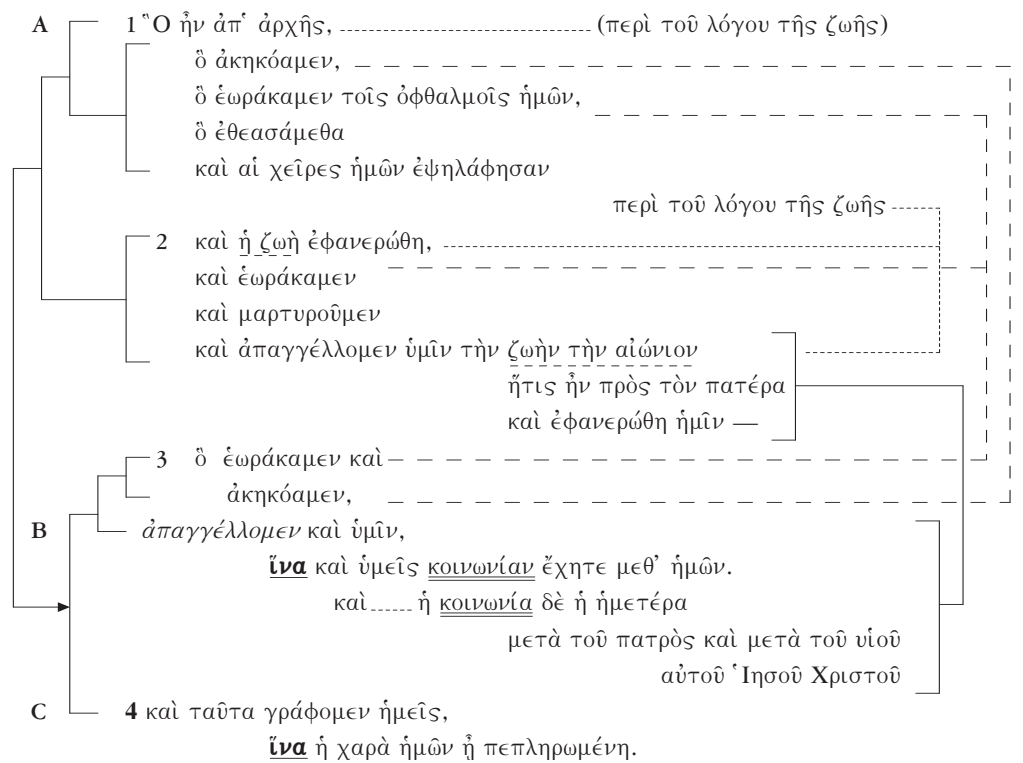


3.2 Discussion of the discourse analysis

From the above discourse analysis it is apparent that there are three sections ( $\mathrm{A}, \mathrm{B}$, and $\mathrm{C}$ ) according to the linguistic relations. These three sections are semantically grouped together by virtue of the actants, "we" and "you", which occur consistently throughout the three sections (Du Rand 1981:3). It is clear that sections "B" and "C" are the objectives for the events spelled out in section " $A$ ", due to the occurrence of the conjunction particle i $\nu a$ (so that) in each section, which refers to intended results (Haas, De Jonge \& Swellengrebel 1972:28; see Du Rand [1981:3] for differences of the above analysis).

The focal point in section " $A$ " (vv. 1,2) is the announcement: кai $\dot{\eta} \zeta \omega \grave{\epsilon} \epsilon \phi \nu \in \rho \omega \theta \theta \eta$ (this life was revealed) (cf. Smalley 1984:9; Du Rand 1981:3). This is due to the fact that 1:1 ends with and 1:2 starts with reference to $\dot{\eta} \zeta \omega \eta$ (the life), which also occurs three times in this section. Although the syntax of verses 1 and 2 "is a difficult complication because of the repetition of accumulative thoughts"11 (Du Rand 1981:4), everything written in this section relates to $\dot{\eta} \zeta \omega \eta$. This life has been revealed by the Incarnation of the Son of God (4:9, 10, 14).

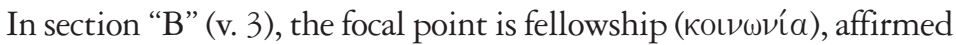
by the double extended í $\nu a$-clause. What was seen and heard has been declared by the Elder to his adherents "so that" (" $\left.\nu^{\prime} \alpha\right)$ they could have fellowship with one another and with the Father and his Son. This relates semantically to verse $2 \mathrm{~d}$ (see analysis).

In section "C" (v. 4), the noun xapá (joy) is not a purpose in itself as in the case of the i $\nu a$ clause in verse 3 , but depends on the esta-

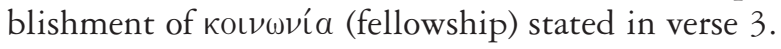

The sentence that began in 1:1, and was interrupted by the parenthesis of verse 2 , is resumed in verse 3 and concluded in verse 4 . The Elder recalls the objective character of the authoritative message which he is "declaring" to his readers; and he announces that its immediate purpose is fellowship (both human and divine, v. 3), while its ultimate intention is joy (v. 4).

11 Dodd (1953:3) refers to it as a "grammatical tangle"; Smalley (1984:5) describes it as a "grammatical complicated sentence." 
From the above discussion the following can be deduced: ${ }^{12}$ Jesus Christ, the Son of God, the life, ${ }^{13}$ accomplished an important revelatorysalvific act so that believers can have fellowship with one another and with God (section A); having fellowship with one another and God is one of the objectives stated for the proclamation of the gospel; "having fellowship with God" is described from the symbolic narrative (environment) of family life where God is the "Father" and Jesus is his "Son" (section B); and finally the joy of believers in this familia Dei (family of God) only becomes "complete" where there is fellowship among one another and with God (section C). These thoughts will now be examined.

\section{4. "HAVING FELLOWSHIP WITH GOD”, AS ONE OF THE OBJECTIVES STATED FOR WRITING THE EPISTLE}

One of the two major themes of the First Epistle of John is fellowship. The Elder wants his readers to have assurance of the indwelling of God through their abiding relationship with $\operatorname{Him}(2: 28 ; 5: 13)$. Therefore, he has written this epistle to encourage this kind of fellowship. In 1 John 1:3 the Elder enunciates this objective. He desires his readers to have fellowship with himself and his associates by sharing their experience of the manifested life $(1: 1,2)$; but fellowship with them meant simultaneously fellowship with the Father and his Son.

12 The starting point is proclamation, however, and not apologetics; it is theology, not ethics. To be sure, these belong together: Christian conduct springs from Christian belief. But here, in the preface, the Elder begins with a positive and uncompromising declaration of the life-giving gospel about Jesus. He confronts his heterodox readers at the outset with the very truth they are denying. As a result we find, both in the preface and in 1 John generally, a Christian manifesto, which was relevant to the situation of the Johannine church, and which is also of timeless significance.

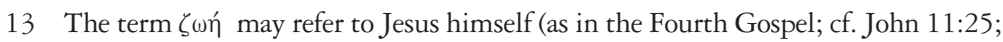
14:6), in which case the writer is claiming that "Jesus was revealed". But as Westcott (1982:8) points out, the term "life" is not to be regarded as a personal

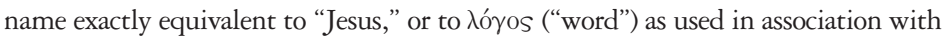
Jesus (cf. John 1:14). Rather, "life" expresses one aspect of his being and activity. 
The noun kotvwvía (fellowship) occurs twice in the prooemium (1:3) and two more times in the rest of chapter one (1:6f.) to create a chiastic pattern as indicated below:

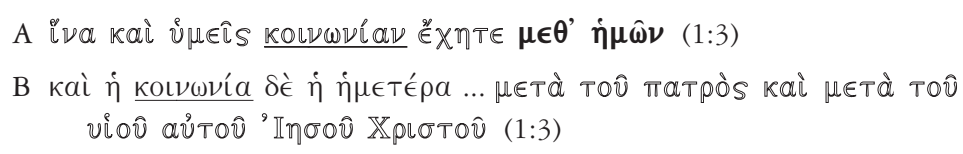

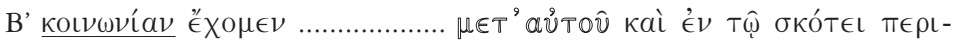
$\pi a T \omega \hat{\mu} \mu \in(1: 6)$

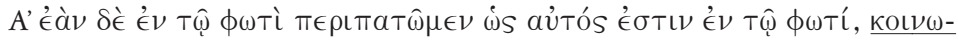

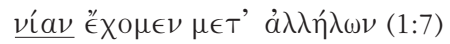

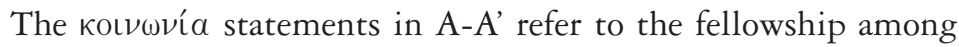
believers, while the statements in B-B' refer to the fellowship which believers corporately experience with the Father and his son Jesus Christ. The function of the chiastic structure here is to emphasise the interrelatedness and interdependence of the fellowship among believers and their corporate ${ }^{14}$ fellowship with God. The one kind of fellowship demands and constitutes the other.

The noun кoเv(v)ía is a richly significant theological term. The Greek word lexicographically means, according to Danker (2000:552), "close association involving mutual interests and sharing, association, communion, fellowship, close relationship." The semantic meaning, according to Louw and Nida (1988:446), relates to Danker's definition: "an association involving close mutual relations and involvement - "close association, fellowship'."15

14 Some tension is evident between the portrayal of God's children as individuals, related to God independently through personal faith, and the corporate dimension of this relationship to God. 1 John underlines the autonomy of the individual child of God $(2: 20,27 ; 5: 20)$, but qualifies this emphasis with the thematic

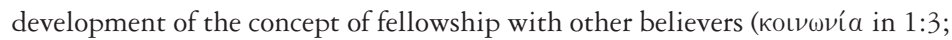
4:6). These titles echo that experience of "communion with God" is also corporate and is constituted through our relationships with fellow believers in this family.

15 In the NT this "mutual sharing" may refer to participation in either material goods, as when Christians in Macedonia and Achaia "raised a common fund"

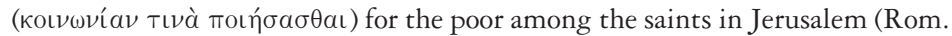

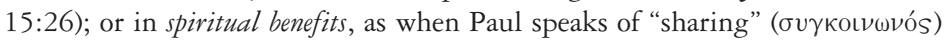


Founded on the above related definitions and based on the adjective

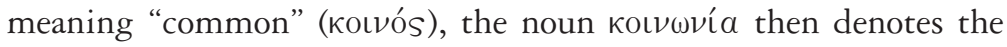
active participation or sharing in what one has in common with others: doing something together or sharing something (Haas, De Jonge \& Swellengrebel 1972:27). The nature of what is mutually shared moulds the character of the group. In this context it refers to the life the believers share with Christ and with one another. This new life in Christ creates and stimulates the desire for such fellowship and calls not for isolation, but for active participation with other believers in this new life. ${ }^{16}$

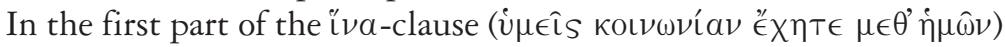
the Elder spoke of fellowship among Christians: a sharing which exists on the human level, even if it derives from a mutual indwelling in

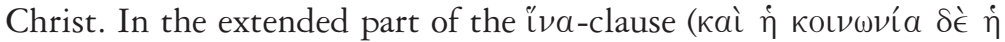
$\dot{\eta} \mu \epsilon T \hat{\epsilon} \rho \alpha \mu \epsilon T \grave{a} . .$.$) , desiring to encourage and advance this Christian fel-$ lowship, the Elder describes the nature of Christian fellowship in terms of its divine origin and operation: "and indeed our fellowship is with the Father and with his Son Jesus Christ” (1:3). This vertical fellowship is essential for true horizontal fellowship. The Elder first says "we have fellowship with one another" (1:7) and this is dependent on "you may

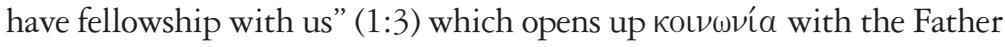
and his Son Jesus Christ (Cf. Painter 2002:128; Rusam 1993:182; Westcott 1982:11). Both these aspects reflect, influence and constitute the other. Both these relationships are theologically "vergleichbar"; both

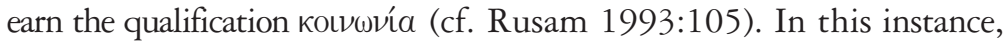

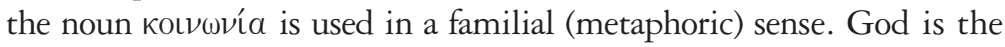
"Father" and the believers "brothers and sisters" to one another. This кoเvovía is thus possible only between Father and children (cf. 1:3, 6).

in the blessings of the gospel (1 Cor. 9:23), or enjoying — in the words of "the Grace" - the "fellowship of the Spirit" (2 Cor. 13:13; cf. also Rom. 15:27). In either sense, the particular "sharing" of Christians, who relate to each other as branches to the true Vine (John 15:1-6), derives from a common faith in Jesus: "We are in him who is true, even in his Son Jesus Christ" (1 John 5:20).

16 The theme "individual freedom" and "responsibility" is not discussed in this article because it does not fall in the scope of this article, but will be attended to in a consecutive article ("Having fellowship with God" in 1 John: dealing with the change in social behaviour). 
Smalley (1997:45ff.) pointed out that the practical dimension of the Elder's theology is evident here, as elsewhere in his epistle. Knowledge of Jesus (see vv. 1, 2, 3a) is to be followed by action (cf. 2:3). Here, the result of "seeing" Christ is a declaration about him (vv. 2-3), and an invitation to have fellowship in him. Christian fellowship then is not the sentimental and superficial attachment of a random collection of individuals, but the profoundly mutual relationship of those who remain "in Christ," and therefore belong to each other (cf. 3:23-24). Just how deep this fellowship can be is indicated by the Greek linguistics in verse

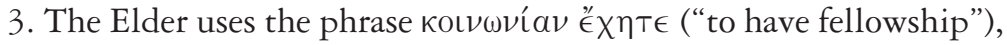

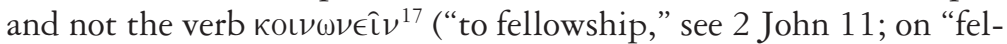

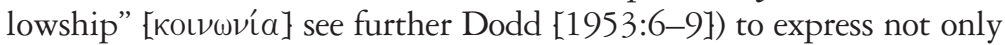
the fact, but also the conscious enjoyment, of fellowship in Christ. The preposition $\mu \in T \alpha \dot{\alpha}\left(\mu \in \theta^{\prime} \dot{\eta} \mu \hat{\omega} \nu\right.$, "with us"), emphasises the deeply reciprocal spiritual relationship that can exist between one Christian and another. The verb "̈x $\chi \tau \in$ (literally, "you may have") in the present tense indicates that this relationship ought to be a continuous act.

The name of Jesus, implicit from verse 1 onward, is at last specified here in verse 3. Christian fellowship is essentially a sharing "with the Father, and with his Son Jesus Christ". With the mention of Jesus, the thought, which was initiated in verse 1 and developed in verse 2 , reaches its conclusion. It is possible, the Elder claims, to receive eternal life and be in communion with its source, because the Incarnation has taken place: "the life was revealed" (v. 2). Through the Son, ${ }^{18}$ God is made known as Father. Moreover, the knowledge of God, revealed through the Incarnation of Jesus (cf. John 17:3), is the common basis for both ideas of "fellowship" described in this verse, the human and divine.

A high Christology is present in this part of verse 3. Jesus is regarded as one (in being and function) with the Father, so that fellowship "with

17 Although Painter (2002:122) points out that the usage of ÉX $\eta T \epsilon$ is characteristic of the Elder, it still does not change its function, as pointed out, in this context.

18 The choice of "Son" as a title for Jesus, is no doubt influenced by the use of "Father" as a designation for God (cf. v. 2; also 2:22-24). Both terms reflect the distinctive "Father-Son" relationship between God and Jesus which is characterised by the fourth evangelist (John 5:21-27; 10:36; 17:1; cf. further Smalley 1998:45). 
the Father" and participation in "his Son Jesus Christ" are treated as parallel and synonymous ideas (hence the Greek formulation $\mu \in T a ́$... кaì $\mu \in T a ́$ : "with ... and with"). As Jesus revealed God, moreover (vv. 1-3), so he made fellowship with the Father finally possible. The Elder's use of the full title, "his Son Jesus Christ," nevertheless points to the human as well as the divine status of the Lord. He was, as typically in Johannine thought, one with man (Jesus, who was "heard, seen, observed, felt," vv. 1-3); and also one with God (his Son, the Messiah, who "from the beginning existed with the Father," vv. 1-2).

This Christological point leads to the next brief investigation on the "fundamental role of Jesus Christ" as arbitrator in establishing fellowship. The principle of a minori ad maius will be used in this regard.

\section{THE FUNDAMENTAL ROLE OF JESUS CHRIST TO ESTABLISH “FELLOWSHIP WITH GOD”}

In 1:1-4 a couple of things about Jesus' role and function in legitimising fellowship between God and these believers can be pointed out: a unique relationship exists between the Father and his Son Jesus Christ (1:3). This Son of God was incarnated into the world so that through him people can come to know God. God's own life has been revealed to believers in his Son. Through Jesus Christ, a person receives God's life because he himself, the Son of God, is the life (1 John 1f, 5; cf. John $1-4)$.

This is the case because a unique relationship exists between the Father and his Son Jesus Christ (1:3). Throughout 1 John, Jesus is mentioned in association with the Father, predominantly with the connotation "the Father of Jesus Christ." ${ }^{19}$ In the Johannine letters this title reflects the intimate, indissoluble unity between the Father and the Son (Coetzee 1993:219). One gets the impression that in his total opposition to the false prophets ( $\psi \in \cup \delta 0 \pi \rho \circ \phi \hat{\eta} T a \mathrm{l}, 4: 1$ ), the Elder wishes to emphasise the intimate bond of love between the Father and Son and their essential unity $(1: 2)$. 
When Jesus is referred to as "his Son" (ó viós aủtov̂, 1:3) or "only"

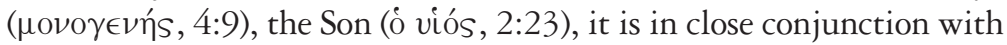
the Father (o maтń $\rho$ ): "No one who denies the Son has the Father, everyone who confesses the Son has the Father also" (2:23; cf. also 1:3; 4:14). A repeated parallelism occurs, effectively putting the Father and the Son on an equal level $(1: 3$; cf. also $2: 23 ; 4: 15 ; 5: 11,12)$ (Edwards 2000:160). The close bond between Jesus as Son and God as Father is such that for the believer the experience of one carries with it experience of the other (2:24) (Lieu 1997:72).

For the Father to communicate bimself to the world, the Son of God had to become incarnate. To prove the reality of his Incarnation, the Elder begins his epistle by emphasising the physical dimension (áкฤкó $\alpha$ -

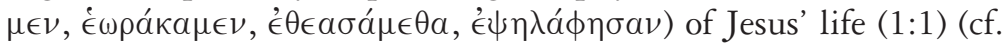
Hiebert 1988:203). He emphasises Jesus' baptism and death (5:6 -

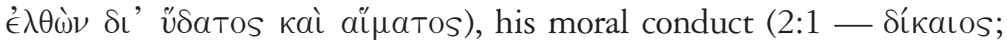

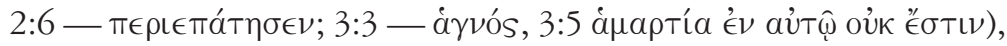

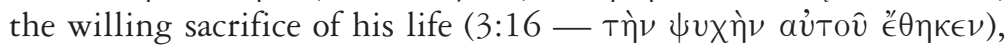

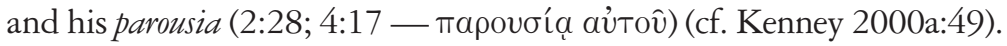
Hence the Christology presented in 1 John is fully incarnational.

In 4:2 the elder states that the confession required from the child of God, to establish that "he is from God", is essentially to acknowledge the incarnation of Jesus Christ. The spiritual outcome of this

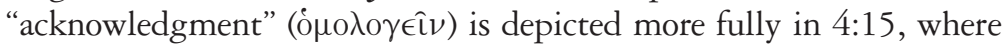
a clear progression of theological thought is present. Such an "acknow-

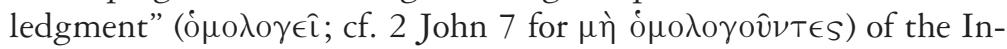
carnation of Jesus (4:2), proclaimed in the tradition (2:24), leads to

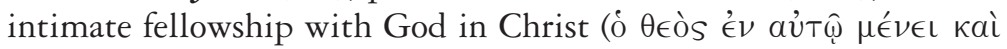

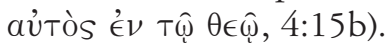

The incarnation was the outcome of the sending of God's only Son into the world so that God's children might live through him. In 1 John 4:9 the

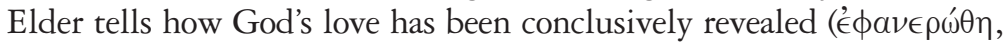
$1: 2)^{20}$ to the Church and the world: “ ... God sent his only Son into the

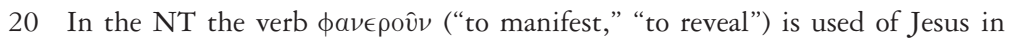
relation to his earthly ministry (1 John 3:5, 8; cf. John 1:31); his resurrection appearances (John 21:1, 14); and his parousia in glory (1 John 2:28; cf. Col. 3:4; 1 Pet. 5:4). Insofar as the Elder here speaks of Christ himself, he obviously alludes 
world so that we might live through him" (4:9). The elder explicitly

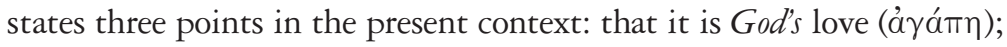
love initiated the plan for salvation $(\zeta \eta \sigma \omega \mu \in \nu)$; that for this purpose he has sent $(\dot{a} \pi \epsilon \in \sigma T a \lambda \kappa \in \nu)^{21}$ his Son into the world.

A comparison of verses 4:9, 10 and 14 indicates that they are similar in their purport:

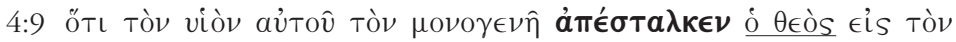

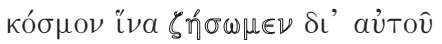

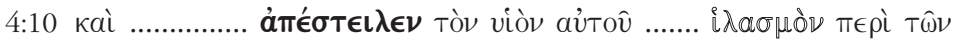
$\dot{\alpha} \mu \alpha \rho \tau t \hat{\omega} \nu \dot{\eta} \mu \omega \hat{\nu} \nu$

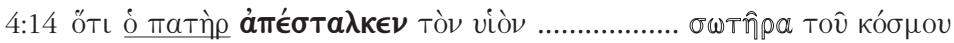

(a) The activity of God described in these contexts, by which his love is manifested, is regarded as salvific in purpose: the Son was "sent" into the world "so that we might live through him" (v. 9), as an "atoning sacrifice for our sins" (v. 10), and as the "Saviour of the world" (v. 14). (b) In each verse it appears that God, the Father of Jesus Christ, is deeply involved in his world and has acted in history for the purpose of man's salvation (Dodd 1946:110f). (c) The saving act of sending

to the Incarnation. The life which is God's gift to man was revealed historically in Jesus. Both concepts present in the Elder's leading affirmation, "the life was revealed", are developed in the closing sentence of this verse (Smalley 1984:9). See Painter

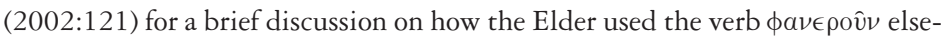
where in this epistle.

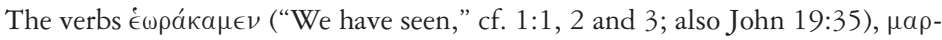

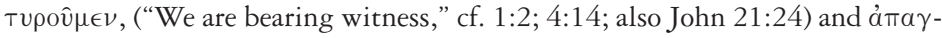
$\gamma \in \hat{\epsilon} \lambda \lambda_{0} \mu \epsilon \nu$, (We are proclaiming," cf. 1:3; also John 16:25) express in order the three ideas of experience, attestation and evangelism, which form part of any genuine and lasting response to the gospel. Using again the theologically significant notion of "seeing," as in verse 1, with a similarly "personal" implication, the Elder stresses the reality of God's revelation in Christ. The divine life was historically manifested and completely visible. Perhaps the Elder is at this point conscious of the need to resist the gnostic inclinations of some members in his congregation who were denying the historical actuality of the incarnation (Smalley 1984:9).

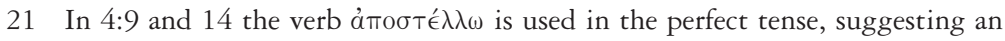
action (of God) in the past, which had a lasting effect (cf. also Haas, De Jonge, Swellengrebel 1972:108). In 4:10 the use of this verb in the aorist tense draws attention to the specific act of sacrifice in which God's eternal love was embodied. 
Jesus involved the serving life, as well as the death, of God's Son. This

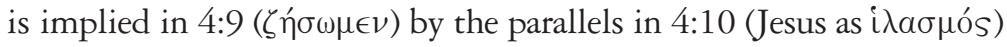
and 4:14 (Jesus as $\sigma \omega T \hat{\eta} \rho$ ). (d) Jesus is described in all three verses as the Son (v. 9, v. 10 and v. 14), who was sent by God so that man could receive and participate in God's life.

The life that God has given to his children is in his Son. In 1 John 1:1f. "eternal life"22 is personified by the Elder, in the person of Jesus Christ (cf. Du Plessis 1978:20). In 5:11f. Jesus is presented as the one who

22 The promise of "eternal life" at the critical point of the letter, after the first introduction of the schismatics, constitutes both the basis for and the goal of the remaining faithful $(2: 25)$. Verse $2: 23$ states that denying or confessing (believe $-3: 23 ; 5: 1,5,10,13$ ) the Son is the precondition for (not) having the Father, which prepares the reader for the promise of eternal life (2:25). The same occurs in verse 5:12, where the statement ó ÉX reader for the definite assurance that they shall "have eternal life" through faith in the Son of God (5:13).

What has been identified so far are the soteriological expressions from a Christocentric perspective: to believe, Son (of God) and eternal life. At the end of chapter 2 (2:29) a new perspective is introduced, but now from a theocentric point of view. This comprises that a "child of God" is someone that has been "born of God" and "abides in God and God in him/her". This perspective does not oppose the Christocentric perspective, but complements it in that it describes salvation from another perspective and simultaneously links the theme of "salvation" with the theme of "fellowship". This is apparent from the fact that the Christian's conduct is demonstrated primarilly through his/her relationship with God (the Father). In the light of the above discussion it can, therefore, be deduced that, Christologically, the centre of the soteriology of the Johannine epistles may be formulated as follows: "Believers can now know for certain that they have eternal life through faith in Jesus Christ, the Son of God." From a theological perspective one might say: "Believers can know that they are children of God (that they are from God) through their birth from God and consequently have fellowship with God."

A convergence of these two perspectives on the centre of soteriology is best spelled out in 5:1-5, where it forms a chiasm and proves to have the same semantic meaning.

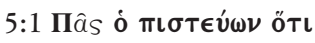

'I

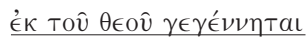

The Christological perspective focuses on the human responsibility: to believe. The theological perspective presents it from the divine side: to be born from God. 
mediates this life given by God. Thus Jesus is life and mediates this life of God. This life originally existed with the Father (1:2); and it is perfectly manifested in God's Son (cf. 5:11b).

The term "life" is a soteriological term, which the Elder explains as "eternal life" 23 and which indicates the quality of existence (cf. Derickson 1993:97; Hiebert 1988:206) in God's family, which God has made available through the earthly ministry of Jesus (5:6; cf. 1:1-2; cf. John $3: 16 ; 17: 2-3)$. It is not to be thought of as life prolonged to infinity, but as a sharing of living fellowship with the Father. This life is characterised by the very nature of God (Hiebert 1988:206) and is a sharing of this life with God (cf. Smalley 1998:287; see Strecker 1996:17ff. for a thorough discussion on $\zeta \omega \eta$ ).

It has been indicated that the Elder's depiction of Jesus was intended to prove to his adherents that Jesus is the Christ (who came with a decisive mission of salvation) and the Son of God (who incarnated in Jesus to reveal himself). Therefore, he is the life for mankind. Only through faith in him can people become children of God and have real fellowship with one another and corporate fellowship with God.

But this fellowship, according to the Elder, realises in a given environment. Instead of using the "church" as reference of the environment in which this fellowship is constituted, the Elder uses the metaphor of "family life." This metaphor is used to describe the richness and the various perspectives of the Christian fellowship.

\section{6. "HAVING FELLOWSHIP WITH GOD," DESCRIBED FROM THE SYMBOLIC NARRATIVE OF FAMILY LIFE}

In his study of first-century Mediterranean persons, Malina (1996:64) came to the conclusion that these people were strongly group-embedded, collectivistic persons. Since they were group-oriented, they were socially minded, attuned to the values, attitudes and beliefs of their ingroup.

23 For this concept see John 17:2-3; also John 3:15-16; 5:24-26; 6:40, 47, 68; $10: 10,28 ; 11: 25-26$. The aorist tense of the verb $\delta i \delta \omega \mu$ emphasises the factual and historical background to God's saving activity. 
Because these people were strongly embedded in a group, their behaviour was controlled by strong social inhibitions along with a general lack of personal inhibition. Their prevailing social institution was kinship; familism was foremost in people's minds. In such a group, recognised principles with common interests and rules (norms), and duties of the members in relation to one another and to these interests exist (Robbins 1996:101).

In the New Testament, Jesus groups are described from this groupembedded, collectivistic perspective, conceiving themselves as forming "the household of God" (familia Dei). Sandnes (1997:156) points out
that in the family terms of the New Testament, old and new structures come together. There is a convergence of household and brother- hood structures. The New Testament bears evidence of the process by which new structures emerged from within the household struc- tures. What we see in the New Testament is not an egalitarian com- munity that is being replaced by patriarchal structures; the brother- hood-like nature of the Christian fellowship is in the making, em- bedded in household structures.

To have a proper understanding of the family metaphors involved, it is necessary to bring together questions about what the documents say and questions about the historical and social contexts of these documents (Sandnes 1997:156).

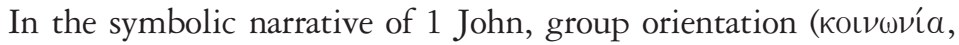
1:3, 6f.) constitutes the socio-historical structural core (cf. Van der Watt 1999:148ff.). ${ }^{24}$ The Elder uses this socio-historical cultural setup of "family-life" to describe the existential reality of being a Christian. Thus, the language used for referring to the adherents of the Elder is strikingly familial. Adams (1983:56) suggests that familial images in written communications can be effective in evoking primary "actions, attitudes, and emotions." By using familial terms, the Elder involves

24 The understanding of the characterisation of the Johannine community relates closely to Robbins' (1996:101) definition of a corporate group:

\footnotetext{
A corporate group is a body with a permanent existence: a collection of people recruited on recognized principles, with common interests and rules (norms) fixing rights and duties of the members in relation to one another and to these interests.
} 
personal cognitive and emotional attachments that exist in early life within the extended family and should apply within the fellowship of believers. Thus, the Elder defines and describes the kind of fellowship that should be constituted and should exist in this Christian community, by applying the best of what he knows about earthly families to the relationship between true believers (cf. Tollefson 1999:85).

The Elder portrays the Christian life as existence in a family, the familia Dei, where God, the Father, is the head. The believers are "children of God" (3:1-2, 10; 5:2), "born from God" (2:29; 3:9; 4:7; $5: 1,4,18)$. They confess that God is "Father" $(1: 2 ; 2: 1,14-15,22-$ 24; 3:1; 2 John 4). These adherents of the Elder are "brothers" (and sisters, 3:13) to each other. The Elder also repeatedly addresses his flock as "little children" $(2: 1,12,28 ; 3: 7)$, and "beloved" $(2: 7 ; 3: 2,21$; 4:1, 7, 11; cf. 3 John 1, 2, 5, 11). Jesus is God's Son (4:15), and the Holy Spirit is the Spirit of God (4:2f.), which constitutes the presence of God $(4: 13 ; 3: 24)$ and guides and educates the believers $(2: 27)$ in the familia Dei.

The highest claim believers can make for their lives, is to claim fellowship with God. This implies that they have come to know the character of God (John 17:3), which has become the transforming reality in their lives. ${ }^{25}$ To become a member of the familia Dei, a person has to be born into it, according to the Elder. This happens through

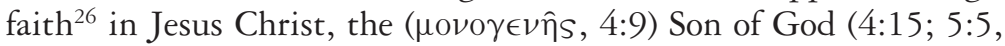
Jesus as Christ [2:22; 5:1], as Son [2:23], and as God incarnate [4:2; 2 John 71). Through such a rebirth by God they have been legitimised

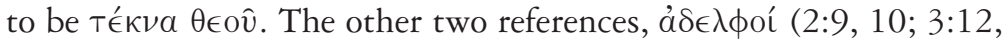

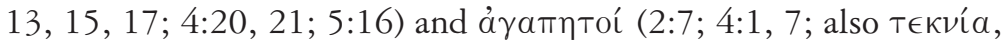

25 In this epistle, the picture of these children (adherents of Elder) is clearly con-

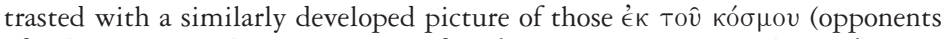
of Elder). In the Elder's comparison of the believers with the world, they become aware of the existential differences concerning status and behaviour between them and the world.

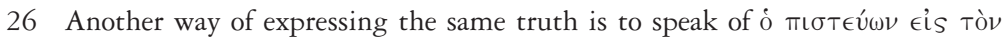
viòv Tov̂ $\theta \in \mathrm{ov}(5: 10)$, ó ÉX

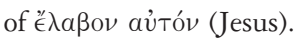


$2: 1,12,28 ; 3: 7,18 ; 4: 4 ; 5: 21)^{27}$ that occur, are forms of address when the Elder speaks to his adherents, but they also spell out some charac-

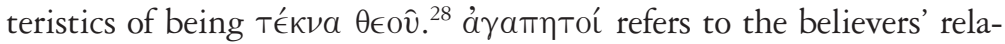
tionship of love with God and fellow believers (cf. 2:5, 10; 3:1, 11, 14, 16, 23 , etc), while $a \dot{\delta} \in \lambda \phi o^{\prime 29}$ refers to their relationship with other believers belonging to the same family. Consequently, it can be deduced that the

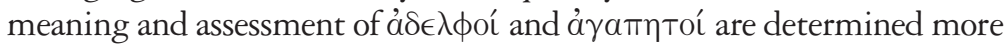

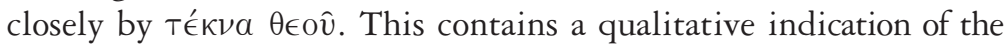
believer's new identity and status as part of God's family (familia Dei), which is, in principle, a communio sanctorum (holy community). It should

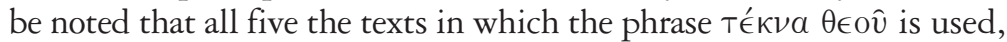

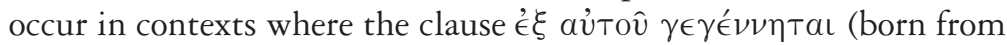
God) is also used $(2: 29 ; 3: 1,2,9,10 ; 5: 1,2,4,18,19)$.

When people became part of God's family, major fundamental changes took place in their lives. The picture of these changes is derived from an analysis of their status and the change in their social behaviour, as depicted by the Elder, and has both individual and cor-

27 Election is emphasised only in 2 John 1 . Only 3 John 15 refers to God's children

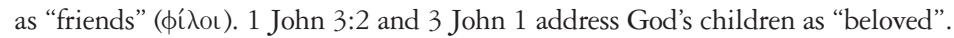
Kenney (2000b:117) points out that privileges attend the children of God in each of the epistles, though not necessarily the same privileges. For example, knowledge of God is emphasised only in 1 and 2 John. 2 John 8 is unique in its men-

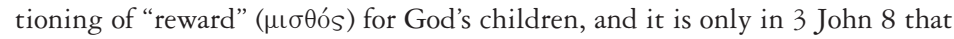

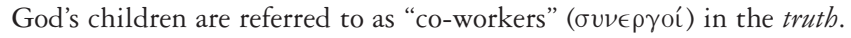

28 This denotation and status of the adherents of the Elder as Téкva $\theta \in \mathrm{\epsilon} v$ is for the first time used in 1 John $3: 1$ and occurs in total only four times in 1 John $(3: 1$, 2, 10; 5:2, 19; cf. also 2 John 1; 3 John 4).

$29 a \dot{\delta} \in \lambda \phi o ́ s$ in the NT denotes "fellow-Christians" or "Christian brothers." In John 20:17 Jesus calls his disciples his "brethren", and he also uses the same term to describe the relations of the disciples to one another (Mt. 23:8; Lk. 22:32). Christians are certainly to view themselves as his brethren or people (Rom. 8:29; Heb. 2:11ff.). The specific relationship of brothers is that of love (1 Jn 2f.) (Von Soden 1964:145; also Louw \& Nida 1988:125). The reference of the adherents of

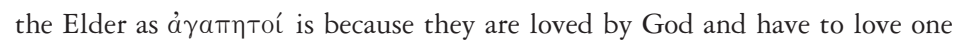
another due to their family relationships as familia Dei. It is within the environment of familia Dei that through spiritual brothers and sisters, the word and the

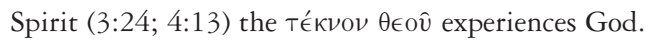


porative implications. The new status and rules of conduct to which the children of God have to conform, are determined by the head of this family. ${ }^{30}$ In 1 John, three definite and provocative statements are

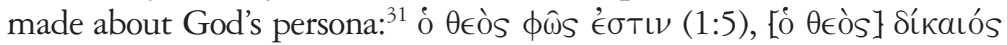

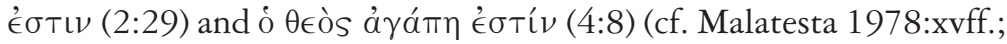
Culpepper 1998:269 and Tollefson 1999:84 for nearly identical analyses of God's nature in relation to the content of the epistle). ${ }^{32}$ According to the Elder, these attributes of God must be recognised and imitated (2:6) by God's children.

This is a spiritual family that supersedes, existentially and ethically, the physical family to which a person belongs. According to the Elder, such a person lives spiritually even while still on earth. This implies that that person exists in a different mode of being on earth — already possessing eternal life. He/she has therefore already acquired membership of another (spiritual) family. Supreme loyalty is owed to this spiritual family. When a person accepts this new way of life, new rules and new values replace previous traditions, rules and values. This birth is essential, for the child of God has to take on the same life as the Father, which must be evident in the conduct of the family. "Family life" then implies specific ethical conduct that relates to the characteristics of God. Therefore, the Elder insists upon a correspondence between internal state and external behaviour. ${ }^{33}$

30 As theology dominates the Fourth Gospel (see Thompson 2001:1ff), 1 John is also theocentric (cf. Lieu 1986:198; cf. also Malatesta 1978:96): it explores the nature of God's character.

31 According to Culpepper (1995:142), believers' "fellowship with God" are constituted, in the light, in truth, in righteousness, and in love — which he calls metaphors for God's nature. He adds the noun $\dot{\eta} \alpha \lambda \eta^{\theta} \theta \in \mathrm{c} \alpha$ (5:6) where the Elder refers to "the Spirit is the truth".

32 Compare Malatesta 1978, Von Wahlde 1990, Culpepper 1998, Kim 1998, Kenney 2000a and Painter 2002. They basically use the same structural division for 1 John, based on the three above-mentioned characteristics about God.

33 Du Rand (1981:31-33) observes the following concerning filiation in the "family of God" according to 1 John: (1) the identification test for filiation in the family of God is "the knowledge of the truth" (2:18-28), (2) the foundation for filiation is "to be born of God" (2:28-3:3), (3) the negative criterion for filiation is "not doing $\sin$, but to live in righteousness" $(3: 4-10)$, (4) the positive criterion for 
However, in the new birth and implanting of the divine seed, the Elder clearly sees something more than a new relationship. It means, according to Ladd (1998:664), that a new dynamic, a new power, has entered the human personality, which is confirmed by a change of conduct. The new birth will reorientate the person's thinking and conduct. A child of God has found a new orientation of his/her will to do the will of God, to love and obey Him, to break with sin and to walk as Jesus did (2:6). ${ }^{34}$ Then, according to 1 John 2:5, 6 (which forms a chiasm), if the child of God lives such a life, he/she will have fellowship with God and will experience his reality. Family cohesiveness and corresponding and mutual loyalty will be manifested and experienced through "right" behaviour towards one another $(3: 10)$.

The existence of obedient members is thus totally determined by their group adherence. If such group adherence and its corollaries are negated, the respective group structures will collapse. Therefore, those who caused the schism in the community are described by the Elder in the most harsh terms. Hence, the depiction of the deceivers in the Johannine epistles, as well as their evil deeds, have to be understood from the dualism of group cohesiveness (familism) in relation to the schism they committed. Therefore, the community (and the Elder) sees the world ${ }^{35}$ as irredeemably evil (Malina 1994:85). The opponents of

filiation is "brotherly love" (3:11-18), (5) the foundation of filiation that "God abides the believer" (3:19-24), and the identity for filiation is "to distinguish between the Spirits of God and the Spirits of the world" (4:1-6). Kotze (1981: 78) observes the following three aspects of filiation: (1) the forensic aspect "a gift of grace that has been reckoned to the good of the believer" $(1: 9 ; 2: 1)$,

(2) the nature aspect - they are "the children of God, not in name only, but by nature" - (3:9), and (3) the ethical feature — "everyone who thus hopes in God purifies himself as he is pure" (3:3).

34 The obligations of the children of God in the family are spelled out in all three Johannine epistles and in each case contribute to an understanding of the behaviour of these children, which is associated with "walking." 1 John 1:6 speaks of the right conduct as walking in the light, whereas 2 John 6 specifies the commandments as the sphere of walking, and 3 John 3 identifies truth as the sphere of behavior (Kenney 2000:117).

35 Here, $\dot{o}$ kó $\sigma \mu \mathrm{s}$ is seen as the domain of Satan, in control of the evil one (1 Jn $5: 19)$. It does not mean 
the Elder are depicted as existing outside this family. They are referred to as "they are from the world" (4:5) and to be "children of the devil" $(3: 8,10) .{ }^{36}$ The Johannine community, therefore, can be regarded as introversionist in its preoccupation with its own holiness (Esler 1994:90). Only within this familia Dei can they experience fellowship with God.

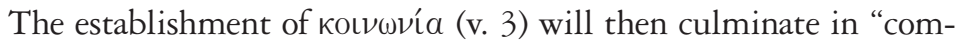
plete joy" (v. 4).

the created universe, nor the human race as such ..., but the life of human society as organized under the power of evil (Dodd 1946:39).

Haas, De Jonge \& Swellengrebel (1972:57) add a personal perspective, namely, that it refers to

all who are, or for all that is, in enmity with God and the believers (see $2: 15-17 ; 3: 1,13 ; 4: 4 f ; 5: 4 f, 19)$. Taken thus it refers to the world and the persons in it as an evil system, as a way of life that is in the power of the evil one and, therefore, is friendly to the false teachers. Then the opposition between "world" and "God" is parallel to that between "darkness" and "light".

Brooke's (1964:47) definition combines the above perspectives: ó kó $\sigma \mu$ os refers to "the whole system, considered in itself, apart from its Maker." This negative perspective about $\dot{o}$ kó $\sigma \mu$ os pictures life outside the family of God. See Haas, De Jonge \& Swellengrebel (1972:56f) for other meanings of $\dot{o}$ kó $\sigma \mu \mathrm{s}$ in the epistles. "Sinners" are seen as those outside the family of God (outside the group) and are (1) labelled according to the sins they committed at ethical level, on account of which they are called murderers (3:15; see also 3:12) and who do not love a brother ( $4: 20$; also cf. $2: 11 ; 3: 15)$, and at the doctrinal level, on account of which they are depicted as deceivers (2 Jn 7; also $1 \mathrm{Jn} 2: 26 ; 3: 7)$, antichrists (2:18, $22 ; 4: 3 ; 2 \mathrm{Jn} 8$ ), liars (2:22) and false prophets (4:1). (2) These sinners are also described within specific relationships: concerning the devil they are seen "as children of the devil" $(3: 8,10)$; in relation to God they are depicted "as not from God" (3:10; 4:3, 6), "do not know Him" (God) (3:1), and do (not) have fellowship with Him (God) (1:6); and finally they are seen as "to be in the world" (4:5). (3) Metaphorically, in a reciprocal sense, it is said that they "walk in the darkness, and do not know the way to go, because the darkness has brought on blindness" (2:11). (4) In probably the harshest description, it is said that such a person "does not have life" (5:12; also 3:15) and "abides in death" (3:14). In most of these references the harsh depiction of the sinners is contrasted with the characteristics of those inside the family (group). 


\section{7. "COMPLETE JOY" THE RESULT OF FELLOWSHIP}

The Elder has already stated (v. 3) that his purpose in writing is the encouragement of a deeply shared fellowship. In 1:4 he adds a further objective: "in order that our joy may be complete!" 37 Thus, the intended result of both the spoken and written good news about Jesus, which forms the basis of John's composition in the prooemium, is "joy". It is a joy which springs from fellowship with him (v. 3; cf. John 20:20), ${ }^{38}$ forms part of the fruit of the Spirit (Gal 5:22), and should characterise the fellowship of all Christian disciples (Acts 13:52; cf. Phil 2:2).

The desire for "complete joy," like the longing for fellowship voiced in verse 3 , is related to a specific and historical situation and does not have to be interpreted in an eschatological or general sense. The Johannine community appears to be threatened with disintegration on account of doctrinal and ethical differences; and the Elder may well be claiming that "our joy" (or the joy of the recipients, if the variant reading is adopted ${ }^{39}$ will initially be completed only when mutual fellowship in Christ among the members of the circle is restored. ${ }^{40}$ Then, and only

37 The phrase "in order that our joy may be complete" (íva $\dot{\eta} x a \rho a \dot{\eta} \mu \hat{\omega} \nu$ ஸे

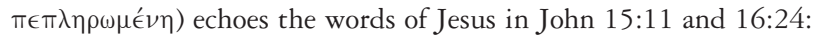

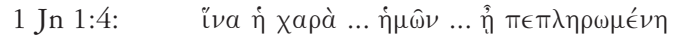

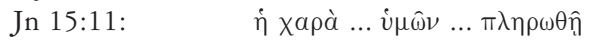

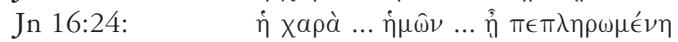

38 The perfect joy of Jesus is due to his full communion with the Father (Jn 14:20) and because he does his will (Jn 4:34). This is to be granted to the disciples also (Jn 15:11). He asks it from the Father in John 17:13, and therefore exhorts his own to abide in him (Jn 15:4) and in his love (Jn 15:9) (Beyreuther 1976:361).

39 There are two textual variants in this verse. See Bruce (1970:39f.; also Painter 2002:123) for a good brief discussion on it. He convincingly points out that there is no crucial change in meaning irrespective of the choice.

40 Smalley (1984:15) places the experience of "joy" on the basis of the restoration of fellowship in the community while Haas, De Jonge \& Swellengrebel (1972: 28) substantiate it on "only when other Christians share that fellowship." These two interpretations do not have to be interpreted as differences, but can rather be seen as complementary, referring to both situations. 
then, the children of God will begin to enter into the joy of their Lord, according to his word (cf. Dodd 1953:9; see further Malatesta 1978:77-90).

Thus, "complete joy" becomes only an existential reality and a realised eschatological experience when God's children experience fellowship with one another (where love relationships exist, new relationships are established and broken ones restored) due to their corporate fellowship with the Father and his Son.

\section{CONCLUSION}

It has been pointed out that a schism occurred in the Johannine community due to different interpretations and understandings of a shared tradition regarding "fellowship with God." To address this problem the

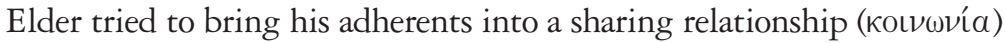

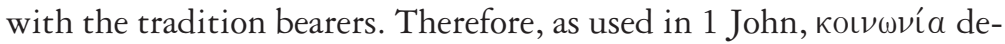
fines the nature of the Johannine "community."

In the prooemium of the epistle, which is used as the basic text, Jesus Christ, the Son of God, is indicated as the one who has life and mediates this life to enable believers to enjoy fellowship mutually and corporately with God. As mediator he is uniquely pointed out and characterised as the one who constitutes this fellowship through his

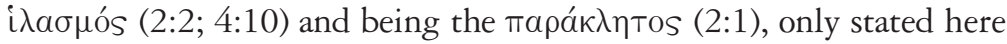
in the entire New Testament. ${ }^{41}$ It is the experience of and fellowship with this Jesus, as risen Lord of the church, through which the experience of God becomes a reality, and which gave the "children of God" their identity. Relationship with (God) the Father and his Son Jesus Christ is dependent on relationship with the community.

Instead of using the church as reference to the environment in which this fellowship is constituted, the Elder uses the metaphor of family life. The environment where the experience of this fellowship is constituted, is described from the symbolic narrative of family life where God is the "Father" and Jesus is his "Son" and believers are the "children of God". Only through one's existence in this familia Dei can true fel-

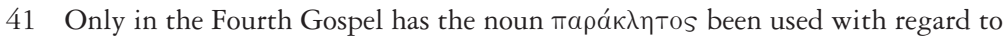
the Holy Spirit. 
lowship, mutually between believers, and fellowship between them and God, be established. Through fellowship with brothers and sisters of this holy community (communio sanctorum) and right conduct by following Jesus' example (2:6), God is experienced and He manifests his involvement in the lives of the Téкva $\theta \in \mathrm{v}$. This metaphor is used to describe the quality and the various perspectives of the Christian fellowship.

\section{BIBLIOGRAPHY}

ADAMS J

1983. The familial image in rhetoric. Communication Quarterly 31(1):56-61.

Beyreuther E \& Finkenrath G

1976. xaí $\rho \omega$. DNTT 2. Exeter: Paternoster Press.

BURRIDGE R A \& GOULD G

2004. Jesus now and then. Cambridge: William B. Eerdmans Publishing Company.

BROWN R E

1982. The Epistles of John. New York: Doubleday.

1997. An introduction to the New Testament. London: Doubleday.

\section{BRUCE F F}

1970. The Epistles of John. London: Pickering \& Inglis Ltd.

Coetzee J C

1993. The Letters of John: introduction and theology. In: A. B. du Toit (ed.), The Gospel of John; Hebrews To Revelation: introduction and theology (Pretoria: N. G. KerkUitgewers, Guide to the New Testament), pp. 201-226.

\section{Culpepper R A}

1995. 1-2-3 John. In G. Krodel (ed.), The General Letters (Minneapolis: Fortress Press, Proclamation Commentaries), pp. 110-144.

1998. The Gospel and Letters of John. Nashville: Abingdon Press.

DANKER F W (ED.)

2000. Greek English Lexicon of the New Testament and other early Christian literature. $3^{\text {rd }}$ Edition BDAG. Chicago: University of Chicago Press. 


\section{DERICKSON G W}

1993. What is the message of 1 John? BSac 150:89-105.

\section{DodD C H}

1946. The Jobannine Epistles. London: Hodder and Stoughton. 1953. The Jobannine Epistles. London: Hodder and Stoughton.

\section{Du Plessis P J}

1978. Die Briewe van Johannes. Kaapstad: N.G. Kerk-Uitgewers.

Du RAND J A

1979. A discourse analysis of 1 John. Neotestamentica 13:1-42.

\section{EDWARDS R B}

2000. The Johannine Epistles. In: B. Lindars, R. B. Edwards \& J. M. Court (eds.), The Johannine Literature (Sheffield: Academic Press), p. 160.

\section{ESLER P F}

1994. The first Christians in their social worlds: social scientific approaches to the New Testament interpretation. New York: Routledge.

\section{Haas C, De Jonge M \& Swellengrebel J L} 1972. A translator's handbook on the Letters of John. London: United Bible Societies.

\section{HIEBERT D E}

1988. An exposition of 1 John 1:1-4. BSac 145:197-210.

\section{HurTado L W}

2003. Lord Jesus Christ. Devotion to Jesus in Earliest Christianity. Grand Rapids: William B. Eerdmans.

\section{KENNEY G C}

2000a. The relation of Christology to ethics in the First Epistle of Jobn. New York: University Press of America.

2000b. Leadership in John. An analysis of the situation and strategy of the Gospel and the Epistles of John. New York: University Press of America.

\section{KIM S H}

1998. Interaction between koinonia and zoe in 1 John. A relational reading. Unpublished dissertation for the degree of Doctor of Theology. University of Stellenbosch.

\section{KoTZÉ P P A}

1981. The meaning of 1 John 3:9 with reference to 1 John 1:8 and 10. Neotestamentica 13:68-83.

\section{LADD G E}

1998. A theology of the New Testament. Grand Rapids: William B. Eerdmans. 


\section{LIEU J}

1986. The Second and Third Epistles of John. Edinburgh: T \& T Clark.

1997 (1991). The theology of the Johannine Epistles. Cambridge: University Press.

\section{LOUW J P \& NidA E A}

1988. Greek-English lexicon of the New Testament based on semantic domains. Vol 1. New York: United Bible Societies.

\section{MALATESTA E}

1978. Interiority and covenant. Rome: Biblical Institute Press.

\section{MALINA B J}

1996. The social world of Jesus and the Gospels. London: Routledge.

\section{PAINTER J}

2002. 1, 2, and 3 John. Collegeville: The Liturgical Press.

\section{RoBbins V K}

1996. Exploring the texture of texts. A guide to socio-rbetorical interpretation. Valley Gorge: Trinity Press International.

\section{Rusma D}

1993. Die Gemeinschaft der Kinder Gottes. Stuttgart: Verlag W. Kohlhammer.

\section{SANDNES K O}

1997. Equality within partriarchal structures: New Testament perspectives on the Christian fellowship. New York: Routledge.

\section{SCHNACKENBURG R}

1984. Die Johannesbriefe. Freiburg: Verlag Herder. HThK 13/3.

\section{SMALLEY S S}

1984. 1, 2, 3 John. Dallas: Word Books. WBC 51.

1998. John: evangelist \& interpreter. Guernsey: The Guernsey Press.

\section{THOMPSON M M}

2001. The God of the Gospel of John. Grand Rapids: William B Eerdmans.

\section{TOLLEFSON K D}

1999. Certainty within the fellowship: dialectical discourse in 1 John. BTB 29: 79-89.

\section{VAN DER WATT J G}

1999. My reading of 1 John in Africa. In: I. R. Kitzberger (ed.), The personal voice in Biblical interpretation (London: Routledge), pp. 142-155.

\section{Von Wahlde U C} 1990. The Johannine commandments. 1 John and the Struggle for the Johannine tradition. New York: Paulist Press.

\section{VON SODEN H F}

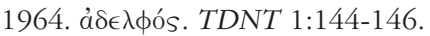




\section{WestCOTT B F}

1982 (1883). The epistles of St John. Johannine studies since Westcott's day by F. F. Bruce. Grand Rapids: William B. Eerdmans.

Keywords

1 John

Fellowship with God

Family metaphor
Trefwoorde

1 Johannes

Gemeenskap met God

Familiemetafoor 